\title{
Chapter 2 \\ How Can We Develop a Co-design, \\ Co-production, and Co-delivery Process \\ Toward a Sustainable Local Society? \\ Comparative Study on Transdisciplinary \\ Research Projects
}

\author{
Yasunori Hanamatsu, Takahiro Fujiwara, Nariaki Onda, Tatsuro Sato, \\ Tomomi Yamashita, and Fumihiko Yokota
}

\begin{abstract}
This chapter will introduce the results of a comparative, interdisciplinary joint research on transdisciplinary research (TD), conducted by three social science researchers and three natural science researchers who work at the Decision Science Center for a Sustainable Society, Kyushu University (Institute of Decision Science for a Sustainable Society, Kyushu University, IDS3). Since the beginning of IDS3's Future Earth project, or before the project became a global research program, all of us had engaged with TD research in our own local fields and disciplines, to solve local social problems while interacting with various social stakeholders. Our disciplines include public health, forest management, natural regeneration in paddy fields, small hydropower generation, local governance, and tourism promotion. While sharing the results of our TD projects among ourselves, we found some common questions and problem perspectives on Future Earth, mainly from the point of view of social science. In this chapter, we will present the outcome of our
\end{abstract}

\footnotetext{
Y. Hanamatsu $(\bowtie)$

Faculty of Law, Kyushu International University, Kitakyushu, Japan

e-mail: hanamatsu@law.kiu.ac.jp

T. Fujiwara

Faculty of Agriculture, Kyushu University, Fukuoka, Japan

N. Onda

Tohoku Research Center, Forestry and Forest Products Research Institute, Morioka, Japan

T. Sato

Disaster Risk Reduction Research Center, Graduate School of Engineering, Kyushu University,

Fukuoka, Japan

T. Yamashita

Academic Research and Industrial Collaboration Management Office, Kyushu University, Fukuoka, Japan

F. Yokota

Institute of Decision Science for a Sustainable Society, Kyushu University, Fukuoka, Japan
} 
comparative joint research, including our common questions, perspectives, and problem setting on Future Earth and TD research. Then, we will propose some hypothetical indicators for the conditions and requirements for achieving successful "co-design/co-production/co-delivery."

Keywords Stakeholding · Scaling · Framing · Coordination · Sensitivity · Legitimacy

\section{Introduction}

This part will introduce the results of a comparative, interdisciplinary joint research on Transdisciplinary Research (TD), conducted by three social science researchers and three natural science researchers who work at the Decision Science Center for a Sustainable Society, Kyushu University (Institute of Decision Science for a Sustainable Society, Kyushu University, IDS3).

Since the beginning of IDS3's Future Earth project, or before the project became a global research program, all of us had engaged with TD research in our own local fields and disciplines, to solve local social problems while interacting with various social stakeholders. Our disciplines include public health, forest management, natural regeneration in paddy fields, small hydropower generation, local governance, and tourism promotion. While sharing the results of our TD projects among ourselves, we found some common questions and problem perspectives on Future Earth, mainly from the point of view of social science. Then, we set up a collaborative research group in the summer of 2017 and held several study meetings to answer our own questions.

In this chapter, we will present the outcome of our comparative joint research, including our common questions, perspectives, and problem setting on Future Earth and TD research. Then, we will propose some hypothetical indicators for the conditions and requirements for achieving successful "co-design/co-production/codelivery" (Future Earth 2013).

\section{Questions and Perspectives}

\subsection{Scale-Sensitivity}

The first problem perspective is the geographical scale of the research topic. Future Earth aims to resolve global issues such as global warming and global-scale loss of biodiversity. We can frequently see several words that focus on the global scale in the Future Earth-related documents such as "dynamic planet," "global sustainability," "global change," "global innovation," "globally recognized model," and "global environmental and social change" (Future Earth 2013, 2014). The Future 
Earth Initial Science Report clearly states that Future Earth will limit its scope to research that helps solve global issues (Future Earth 2013). On the other hand, the effects and responses to non-global geographical and spatial scales such as national, regional, and local are also mentioned. However, they are recognized just as an "object" affected by global environmental change, or as a "means" to take action toward global sustainability. In particular, local scales and actors must be mobilized for global problem solving, and local-scale initiatives are expected to be "scaled up" to a global scale (Future Earth 2013, 2014).

However, in our experience of TD research for problem-solving on a local site, various initiatives for sustainability on local sites are not necessarily taken for the purpose of resolving global issues. Sustainability problems that arise only within a local context are certainly present and being tackled on a local scale, in line with the actual needs of the relevant local communities. They may eventually lead to global sustainability; however, this is not their main purpose. Local stakeholders are rarely aware of the scale-up logic. They may use global knowledge such as academic knowledge in the problem-solving process. However, resolving local issues in cooperation with local actors to meet local needs does not aim at global sustainability. Then, are such local-scale initiatives toward local sustainability not covered by Future Earth research?

How is the hierarchy that the upper, global scale is given priority over the lower, local-scale justified? (Jasanoff 2010; O'Brien and Barnett 2013; Turnhout and Boonman-Person 2012; Jonas 2015). Environmental changes are extending on a global scale, yet the act of prioritizing the global scale as the main object and purpose of problem-solving creates yet another problem. Scale-setting or scale-framing that gives a priori priority to the global scale is a political action in itself, referred to as "politics of scale" by scholars of political geography (Kurtz 2003; Smith 1992; Swyngedouw 1997, 2004; Yohannan et al. 2014). By putting too much emphasis on global environmental change and sustainability, Future Earth seems to have fallen into a trap of "scale politics" whether consciously or unconsciously.

On the other hand, are there any local problems or solutions that do not directly have global implications but are not at all related to the problem of global scale, both physically and epistemologically? From the perspective of political geography, global is not a scale that exists independently of the local scale; rather, it is an accumulation of locality. Therefore, we can say that the reality of the global is "multi-local" (Herod 2011). On the other hand, from the viewpoint of governance, the idea of "multi-level governance" is important. In this concept, various governmental and non-state actors that have a cross-scale jurisdiction of global, regional, international, national, and local, will set and solve a problem while always interacting in a networked system (Bache and Flinders 2004; Latham 2002). In addition, the concept of multilevel governance does not employ any hierarchy that prefers a particular scale. It assumes that the political relationship between scales is "flat" and that different scales or frames can coexist (Jonas 2015; Yohannan et al. 2014). Therefore, the problem setting itself, which might initially focus on a single scale, is likely to change by interacting or communicating with other scales. 
In this way, resolving local issues based on local needs in a local field should be included in the scope of Future Earth research, without premising that such local initiatives will directly contribute to sustainability on a global scale or will be scaled up to the global scale. Otherwise, the research range of Future Earth will be very limited and the value of Future Earth research will be reduced, while seemingly geographical scale is extended to the global scale.

\subsection{Can Science Transform Society for Sustainability?}

The second perspective is the relationship between "social transformation to sustainability" and the role of science. Future Earth aims for social transformation toward global sustainability. For that purpose, Future Earth will "deliver products and services that we societal partners need to meet these challenges," and these "products and services" refer to "integrated Earth system models" and "sciencebased data, tools, and resources" (Future Earth 2014). Furthermore, Future Earth will "pioneer approaches to co-design; and co-produce solutions-oriented science, knowledge, and innovation for global sustainable development" (Future Earth 2014). Such "science" and "knowledge" refer to not only natural sciences but also to those co-created with social science, humanities, and social partners (partners in society). However, it is assumed that some scientific or technological models and tools are developed, and based on them, social transformation is promoted.

Why do we have to transform society based on scientific knowledge, tools, and assessment? Are scientific methods and knowledge really needed to enhance the sustainability of society? Is it impossible to create a sustainable society without science? (Brown et al. 2010). Is it possible for science and scientists, who value neutrality and objectivity, to be a player in social transformation, along with other social stakeholders? (Pielke 2007).

Future Earth stands on the premise of the possibility and legitimacy of social transformation based on science. In this respect, Future Earth depends on the assumption that science will respond to the needs of and be useful for society. However, at the root of the concept of "useful science for society", there is an excessive expectation for science, as if scientific development will automatically contribute to the solution of problems such as global environmental problems (Asayama et al. 2017). From the viewpoint of social science, it is necessary to question the premise itself. In other words, the usefulness, efficacy, and acceptability of science or scientific methods for society must be considered and verified. Further, one should ask, on what conditions scientific knowledge, tools, and resources can help to improve the sustainability of society? In short, one must critically reconsider the premise "science can transform society for sustainability."

The problem of environmental change and sustainability-Future Earth's main target - is a problem of scientific uncertainty and a conflict of values. Therefore, it is often said that it is difficult to solve this problem only by the power of science. Such inherent problems in science have been noted in recent years as "trans-science" 
(Weinberg 1972), “post-normal science” (Funtowicz and Ravetz 1993), “wicked problems" (Brown et al. 2010), and so on. This also indicates, on the contrary, that various nonscientific elements can influence social transformation. In that sense, the validity of the scientific method, the reasonable range of science toward social transformation, and the relationship between "scientific" and "unscientific" must be re-examined in resolving sustainability problems at all scales.

\subsection{Interdisciplinary Research}

The third perspective is the method of cooperation between natural science and social science in Future Earth research. Future Earth does not necessarily look at research only from a natural scientific perspective. It also strongly urges social scientists to collaborate with social stakeholders and links with social policies and practices (Stafford-Smith et al. 2012). In addition, it also recommends the complete "integration" of all scientific disciplines, including not only natural and social sciences but also humanities and science technology (Future Earth 2013, 2014). However, in the Future Earth documents, such "integration" first assumes the problem setting or goal of "global sustainability" and "social transformation" as set up by natural scientists. Then, it requires social scientists to develop a method to promote social transformation, to analyze and evaluate social issues and impacts arising in the course of social transformation, and to identify sociocultural, economic, institutional, and political barriers that discourage social transformation (Future Earth 2014).

However, is the role of social science only to implement the research design drawn by the natural sciences and to carry out a "saucer" to examine the social effect and influence of the research implementation? (Werlen 2015; Hanamatsu 2012). Is social science a contractor for the work of developing methods to solve the problems set by natural science and practice at the social level? Have social scientists been given sufficient opportunity to share a critical examination of the appropriateness of the problem settings and goals presented by natural science? (Werlen 2015). Fundamentally, the role of social science is to critically examine and recognize from all angles all phenomena, ideas, and representations that arise or may arise in human society. In that case, social scientists must examine the Future Earth project itself and critically reconsider Future Earth's way of problem setting such as global sustainability and social transformation. While Future Earth is aimed at "solutions-oriented research" (Future Earth 2014), social science is quite sensitive about who, and for what purpose, determined the problem setting and goal so that a solution can be offered afterward. In other words, we must look at the natural scientific view of "nature" and "world" that appears in the method of problem setting.

Similarly, the recent discussion of the "anthropocene" is based on the image and framing of the "desirable climate" or "desirable environment" provided by natural scientists, emphasizing the tremendous damage of climate change and the urgent need for a response. This trend requests all humankind and society to tackle such 
urgent problems as if such a contribution was "fatal" and "inevitable" (Zalasiewicz et al. 2010). Even though climate change came to be extensively discussed in the political realm, it has been pointed out that "de-politicization" has occurred in that it becomes difficult to put objections to the problem setting and recognition (Swyngedouw 2011; Lövbrand et al. 2015). In this sense, social science must not only reveal the ideal way of using science and technology from the perspective of society, the appropriate position of scientists in society, and the conditions in which society accepts science and technology, but it should also re-examine critically and politically how the problem setting by natural science will affect people and society (Swyngedouw 2014).

Interdisciplinary research and integration of scientific disciplines do not imply that one discipline should capture the other. It is crucial to recognize that natural sciences and social sciences have their own unique logic in their purpose, culture, object, perspective, and methodologies. This is the starting point that could turn interdisciplinary research into a fruitful success (Werlen 2015). Three social scientists from our research group have been actively involved in collaborative research with natural science researchers. They have conducted cross-disciplinary research activities while utilizing the knowledge of both social science and natural science. The other three are natural scientists; however, since they have been involved in the local community for their research for a long time, they have a wealth of social experience and insight into society. Therefore, we thought that we should all share this understanding of interdisciplinary research and undertake a critical study of Future Earth research where the impact of natural scientific ideas seems to be strong, from the perspective of social science.

\subsection{What Is Society? Who Are Stakeholders?}

The fourth perspective is the need for a concrete consideration of "society" and "social stakeholders." Future Earth recommends collaboration between science and society in response to global environmental change and realization of global sustainability (Future Earth 2013). However, in the Future Earth documents, the image of "society" is unclear; it is a general and abstract image. As a result, it seems to assume a planar, flat, abstract, and single society. However, society is originally diverse in context, multi-layered, and individually specific. It includes families, companies, schools, circles, civic organizations, settlements, districts, municipalities, states, national relations, regions, and the global. There exists different type of societies at all scales. What kind of society can Future Earth envision for its purpose?

In addition, Future Earth recommends that the knowledge necessary for social transformation should be created together with social partners (partners in society, or societal partners) or "stakeholders" (Future Earth 2014). What kind of people and organizations does Future Earth assume as partners and stakeholders in society? While any person who has interests in a problem or issue can be considered a 
stakeholder, what kind of stakeholders does Future Earth research expect to cooperate with?

The Future Earth Initial Science Report enumerates major stakeholder groups in Future Earth studies: academic research (scientists, research institutes, universities, and scientific committees), research funders, governments (national, regional, and international), development groups (e.g., the World Bank), business and industry, media, and civil society (e.g., NGOs) (Future Earth 2013). As such, Future Earth seems to focus on people and organizations that have an influence on global social transformation and that can rationally act (Future Earth 2014). However, can we say that we have successfully collaborated with the "society" itself only by cooperating with specific governmental agencies or NGOs? Is this not just working with some of the social entities that exist at a certain level or scale of "society"? In other words, only a convenient subject that is useful for the transformation of society can be selected and recognized as a "stakeholder." As we will see later, such a political selection of stakeholders should be called "stakeholding" (Freeman et al. 2010; Mitchell et al. 1997). How should such "stakeholding" be done in Future Earth studies?

Also, are we researchers and scientists well aware that we will participate in a collaborative work as one of stakeholders who stand on equal footing with other stakeholders? Is it possible for scientists to participate as a stakeholder with a substantial interest and simultaneously be able to balance the "neutrality" and "objectivity" that scientists consider important? Furthermore, is it possible for scientists and researchers to be responsible for the role of the coordinator who is essential for working with society? The position of researchers and scientists in the collaborative process is a critical matter. However, Future Earth does not pay attention to this point.

The tendency of Future Earth to simplify and overgeneralize the concepts of "society" and "social stakeholder" is indeed paradoxical. Environmental and sustainability research deal with environmental change at the global level, and an urgent response to it as "the problem of human dimensions" (Future Earth 2013). As a result, on the one hand, the need for an urgent response to environmental change at the global scale has come to be properly understood; on the other hand, understanding of the diversity, multilayeredness, and dynamic change in society, and the social sensitivity to various concrete people and groups who live and work in a society is being lost (O'Brien and Barnett 2013). In other words, the greater emphasis on the influence of environmental change on the "human species" conversely deprives people of a concrete concern for individuals, societies, and stakeholders. This trend will reduce the value and scope of Future Earth research that seeks to collaborate with society.

The kind of society in which we often collaborate in TD research is the "local society." In such local societies, the local government and local businesses, illustrated by Future Earth as major stakeholders, are just part of the society; they are not representative of the local society. Then, is it possible to say that we collaborate with society itself by merely cooperating with such kind of people and organizations? Local people or residents are the main components of local society. In the 
stakeholders' list of Future Earth documents, local people seem to be classified as "civil society." However, "civil society" is a very ambiguous and controversial concept, and there is a wide variety of definition and scope in what kind of persons are actually contained in "civil society" (Ehrenberg 2017). For example, a subject that is independent of the government, forms a nonprofit organization, and actively and rationally participates in a public political space is often referred to as civil society. In Future Earth documents, NGOs and indigenous peoples are often cited as civil society. Therefore, it is understood that Future Earth considers civil society as an active subject in social transformation. However, people living in a local society are not only such active residents. There are both "good citizens" and "bad citizens." It is often the case that many local people are regular citizens who are non-rational and indifferent to public matters (Edwards 2014). Actual collaboration with local society always requires a close relationship with not only active citizens or organizations but also concrete individuals who are, in some cases, indifferent or negative to public matters. Therefore, it is not possible to talk about collaboration with local society without communicating, discussing and cooperating with a concrete local society composed of such various individuals and organizations. Our research experience with the local society is likely to provide new insights into Future Earth research that tends to emphasize collaboration with society through a general and abstract image.

\subsection{Taking the "Co-design/Co-production/Co-delivery" Process Seriously}

Finally, the fifth perspective is about the meaning and purpose of "co-design/coproduction/co-delivery" between science and society in Future Earth research. As mentioned above, Future Earth aims at "solutions-oriented research" and is intended to acquire scientific knowledge to respond to environmental changes and sustainability at the global scale. To obtain such scientific knowledge, scientists and social stakeholders are asked to cooperate with each other for "co-design/co-production/codelivery" of knowledge (Future Earth 2014). In other words, Future Earth regards "co-design/co-production/co-delivery" as a means to obtain scientific knowledge that can lead to the resolution of problems set up by Future Earth. "Knowledge" (not necessarily scientific) which is obtained by "co-design/co-production/co-delivery" with social stakeholders, and "scientific knowledge, insights, data, and tools that scientists will acquire" are clearly distinguished. Here, unfortunately, Future Earth does not recognize that we can form a new type of knowledge that combines the extrascientific knowledge, perspectives, and experiences of social stakeholders, with the scientific data and the knowledge of academic experts (Van der Hel 2016). In Future Earth, "co-design/co-production/co-delivery" in collaboration between science and society is merely a means to justify that science is relevant and useful to society by showing that science is trying to meet the needs of society and that society accepts science as its user (Van der Hel 2016). Therefore, the knowledge obtained in 
the process of "co-design/co-production/co-delivery" is neglected, and just the fact and alibi that "co-design/co-production/co-delivery" of knowledge is successfully done might be overemphasized.

However, as explained throughout this part, from our experiences of TD research on local sites, "co-design/co-production/co-delivery" is not a justification for the usefulness of science; it is a direct way to improve sustainability in local societies. The reason is that any effort to improve the sustainability in a local society is virtually impossible without trying to achieve the "co-design/co-production/codelivery" with local stakeholders.

In recent years, in Japan, collaboration between universities including scientists and researchers and the local society is currently being actively implemented as an important objective, because "co-design/co-production/co-delivery" with the local society will have a great educational effect on university students and may also contribute to the revitalization of the local society. In such cases, the goal is not to acquire scientific knowledge or justify the usefulness of science.

Moreover, "co-design/co-production/co-delivery" with society cannot be easily achieved. It requires a lot of time, effort, money, and intellectual resources. In other words, "co-design/co-production/co-delivery" with society is not easy enough to be regarded as merely a means to acquire scientific knowledge for global sustainability (Moser 2016). In that sense, collaborative "co-design/co-production/co-delivery" with society is not an alibi for scientists but a major research activity and objective for achieving a sustainable local society.

On the other hand, science should be regarded as a factor that might work in the collaborative "co-design/co-production/co-delivery" process. In other words, science or scientific knowledge can be perceived as one of the driving forces and means to promote successful "co-design/co-production/co-delivery."

In this way, our questions on Future Earth and TD research from a social science perspective are as follows. What kind of conditions, requirements, factors, and processes can enable "co-design/co-production/co-delivery" with society to successfully work? Does science or scientific knowledge actually work as a driving force to promote "co-design/co-production/co-delivery?"

\section{Problem Setting}

Based on the above-mentioned issues, we set the following problem as a common viewpoint of joint research. Our interdisciplinary research group worked together to compare projects that have long tried to promote "co-design/co-production/co-delivery" with society for developing a sustainable local society. Then, we found some common perspectives for re-examining Future Earth research and developing more fruitful TD research. At what kind of scale does "co-design/co-production/co-delivery" tend to work better? What kind of conditions or factors are required for successful "co-design/co-production/co-delivery?" What kind of stakeholders should we cooperate with? What kind of processes should be followed? To sum 
up, what kind of conditions, factors, and processes are necessary for a good "codesign/co-production/co-delivery"?

The key points about this problem setting are as follows. We should focus on the "co-design/co-production/co-delivery" process in a specific local society rather than a general abstract society, without premising that such a process will necessarily make a connection or direct contribution to the solution of global problems such as climate change and global sustainability. We should also focus on what kind of processes "co-design/co-production/co-delivery" will follow, and what we should pay attention to during each phase of the process, rather than emphasizing a fact or result of the "co-design/co-production/co-delivery" in a local society. Furthermore, we must properly understand that there are various overlapping scales in a local society (e.g., settlement, village, town, city, area, region, municipality, and province). In addition, we must recognize that stakeholders are often specifically selected as candidates from among the many actors or organizations, and understand that diverse "framings" of the problem can be simultaneously constructed by each stakeholder and that in some cases a gap or misfit can occur between these "framings." Moreover, from the social science perspective, it is also important to consider who should evaluate the process and results of the "co-design/co-production/codelivery", because the consequences of the final assessment may change depending on the "framing" or perspective of the evaluator.

Society is a living subject created by whimsical humans. Therefore, the conditions, requirements, factors, and processes of "co-design/co-production/co-delivery" with society are not necessarily arranged from a genuinely scientific perspective. Likewise, other valuable knowledge that can be obtained during "co-design/coproduction/co-delivery" is not necessarily scientific. However, we think it is important to rearrange them based on our own indicators from the social scientific perspective. Such indicators remain hypothetical; however, they can be a useful tool for clarifying the conditions, requirements, factors, and processes that would ensure successful "co-design/co-production/co-delivery."

\section{Hypothetical Indicators}

The indicators to measure the conditions, requirements, factors, and processes for promoting successful "co-design/co-production" are divided into four categories. First, Gap Analysis Indicators (GAI) verify consistency or gaps in understanding and perception among stakeholders about the collaborative work. Second, Social Consideration Indicators (SCI) show various matters requiring the attention of stakeholders and coordinators. Third, Social Evaluation Indicators (SEI) are considered in the social evaluation phase after the completion of co-production. Fourth, there are other considerations classified as Additional Factors (AF).

The hypothetical indicators which seem to belong to each category are as follows. All of these constitute a checklist that scientists and researchers need to carefully consider when collaborating with a local society. Again, it remains hypothetical, but 
we think it is the most comprehensive list of indicators to date, enumerating all the factors that are considered important for comparing the Future Earth projects of our joint research members (Yokota et al. 2018).

However, we understand that it may not be a complete checklist that can be applied to other projects. In addition, we have not yet clarified which indicators are more important than others in each phase, what the conditions must be met in any "co-design/co-production/co-delivery" project, or whether there is a logical relationship between each of the indicators. We will examine such issues in future studies.

\subsection{Gap Analysis Indicators}

\subsubsection{Stakeholding}

Are appropriate people and organizations correctly selected as "stakeholders" who have a direct or indirect interest? How does the dynamic membership process of including or excluding stakeholders work? Which kinds of stakeholders are selected for what kinds of purposes? What method is used to set up a "limit" of the appropriate stakeholder?

\subsubsection{Scaling}

What is the geographical, human relational, and jurisdictional scale appropriate for dealing with the problem? How, and by whom, is such scaling set up? Does the problem originate from and can be resolved in a single scale or does it require multilayered scales?

\subsubsection{Framing}

From what point of view, and by whom, is the phenomenon recognized as a "problem"? Do all stakeholders agree on a single frame for the problem, or is there conflict over various possible frames? Can plural frames converge at a common perspective and coexist or do they clash with each other?

\subsubsection{Priority}

Is the problem properly recognized as something that should be prioritized among a myriad of "problems" in a society of the specific scale? Who, and by what criteria, decides the priority of problems, and what is their process? 


\subsubsection{Accountability}

Who is responsible or accountable for the processes and results of resolving the problem? Is such a responsibility actually to be carried out? Do stakeholders successfully divide and share the task of problem-solving?

\subsubsection{Time Setting}

How much time is allowed for resolving the problem? To what extent is the problem an emergency? What is the time range necessary to solve the problem? Who can decide on setting the time?

\subsubsection{Transition Process}

If gaps occur in indicators 4.1.1-4.1.6 between stakeholders, does the transition process for coordinating these gaps properly function?

\subsection{Social Consideration Indicators}

\subsubsection{Coordination Subject}

Who coordinates, or who should coordinate? Is the coordination appropriate? Scientists and researchers are not necessarily responsible for the coordinator. In the context of independence and neutrality in science, other stakeholders (rather than researchers or scientists) should take on the responsibility of acting as coordinators. However, scientists or researchers may have to become coordinators reluctantly, depending on the course of problem.

\subsubsection{Social Sensitivity (Awareness of Societal Sensitivity)}

Can a coordinator understand and carefully consider the human relationships, history, culture, viewpoints of residents, and intrinsic diversity that exist in a society? Can they fully comprehend the sensitive nature of a society?

\subsubsection{Social Capital}

Does a coordinator have an established relationship of mutual trust with stakeholders and other people or organizations in local society? Do they carefully consider the various human relationships embedded in local society? (Putnam 1993, 2000). 


\subsubsection{Fairness/Justice}

Does a coordinator demonstrate fair consideration for each stakeholder who has a different framing or priority in the decision-making processes?

\subsubsection{Independence/Neutrality}

Do stakeholders responsible for coordination roles (especially, scientists and researchers) successfully take an independent, neutral position toward all other stakeholders? Do they fully understand that, in some cases, they will act as one of the stakeholders and cannot remain neutral on a problem?

\subsection{Social Evaluation Indicators}

\subsubsection{Legitimacy}

Is the result of the "co-production" to be evaluated as legitimate or relevant by the wider society consisting of specialists, citizens, and potential stakeholders, distinct from the internal evaluation by the stakeholders directly involved in the "co-design/ co-production" process? Would the decision-making process be regarded as legitimate by an outside observer? If the result of a "co-design/co-production" project receives a positive evaluation as legitimate by an outsider, it will be applicable to other cases, and finally, the phase of "co-delivery" (dissemination of results) will begin.

The indicator of legitimacy concerns both rationality (or relevance), which requires proper processes, and traditionality (or orthodoxy), in that the "co-production" follows the history, traditions, customs, and culture of the society (Coicaud 2002).

\subsubsection{How to Decide?}

How is the plan and method for the collaboration project decided?

\subsubsection{Who Decides, for Whom and to Whom?}

Who decides to start and implement the collaboration project, for whom and to whom? 


\subsubsection{Usefulness of Science}

Are scientific knowledge and technology useful and effective for the planning and implementation of a collaborative project? How effective is the usefulness of science and can stakeholders successfully have trust in science regarding the "co-design/coproduction/co-delivery" process distinguished from the authority or power that specific universities, researchers, and scientists usually have? When the usefulness of science is recognized, does it mean that the effectiveness and legitimacy of the scientific data and knowledge itself are evaluated, or the validity and significance of the act of "using science" are socially approved?

\subsubsection{Social Sensitivity}

Do stakeholders understand and carefully consider the human relationships, history, culture, viewpoints of residents, and intrinsic diversity that exist in a society? Can they fully comprehend the sensitive nature of a society?

\subsection{Additional Factors}

\subsubsection{Personality}

What kinds of impacts do the position, character, and personality of each stakeholder (especially those who show important leadership) have on the "co-design/co-production/co-delivery" process? Do the processes and results of "co-design/co-production/co-delivery" depend on the personal factors of a stakeholder?

\subsubsection{Integration of Scientific Research and Education}

Is the project conducted only as "scientific research" by researchers and scientists, or is it also combined with an educational program? In the latter case, does the integration of scientific research and education actually promote a successful "codesign/co-production/co-delivery" process?

\section{Hypothetical Timeline}

Based on the hypothetical indicators for assessing "co-design/co-production/codelivery" as mentioned above, Fig. 2.1 shows a hypothetical timeline of the co-design, co-production, and co-delivery process. It also briefly indicates which 


\section{Stage 6}

co-delivery start

application to other cases

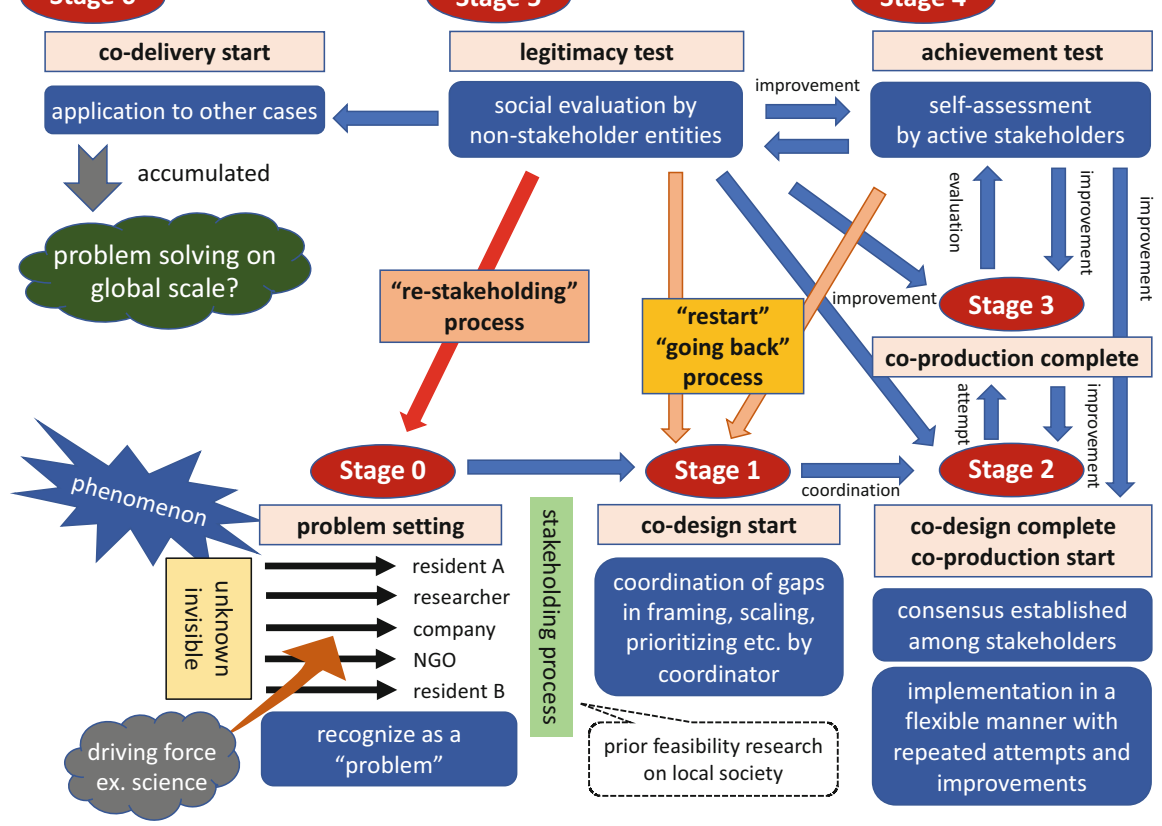

\section{Stage 5}

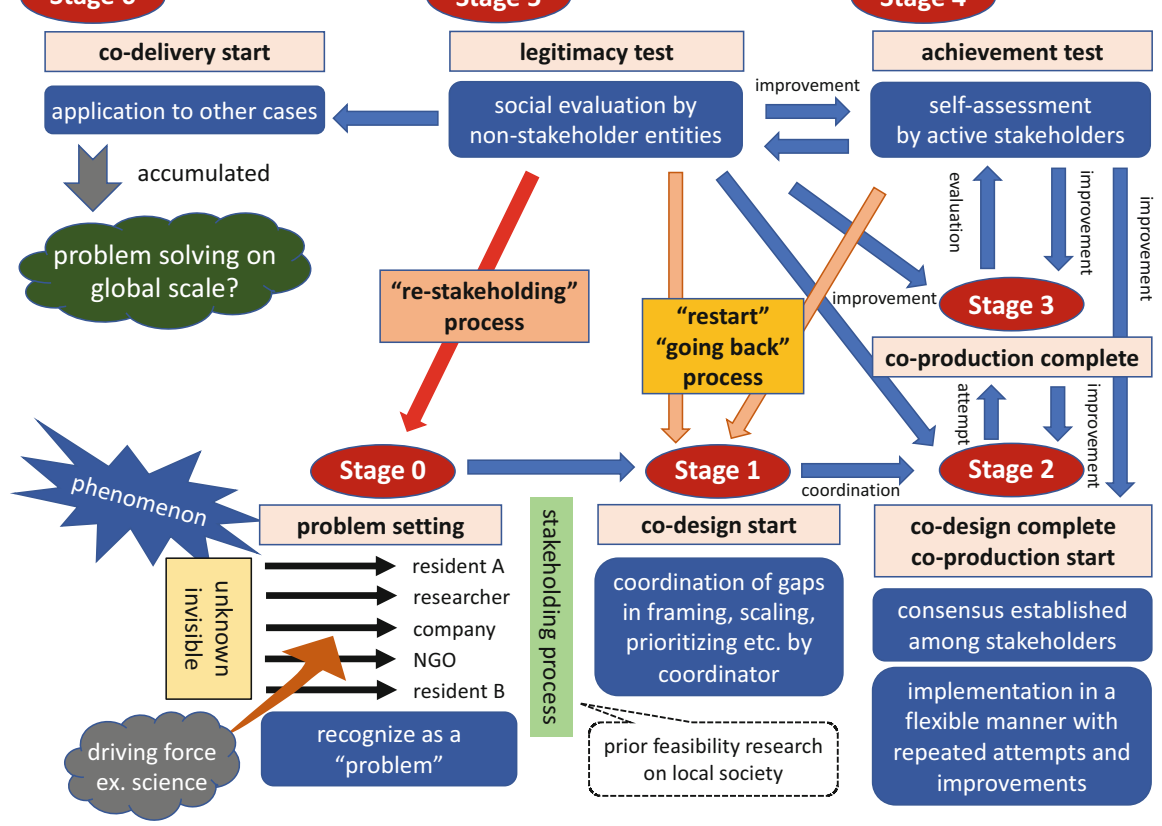

\section{Stage 4}

by active stakeholders

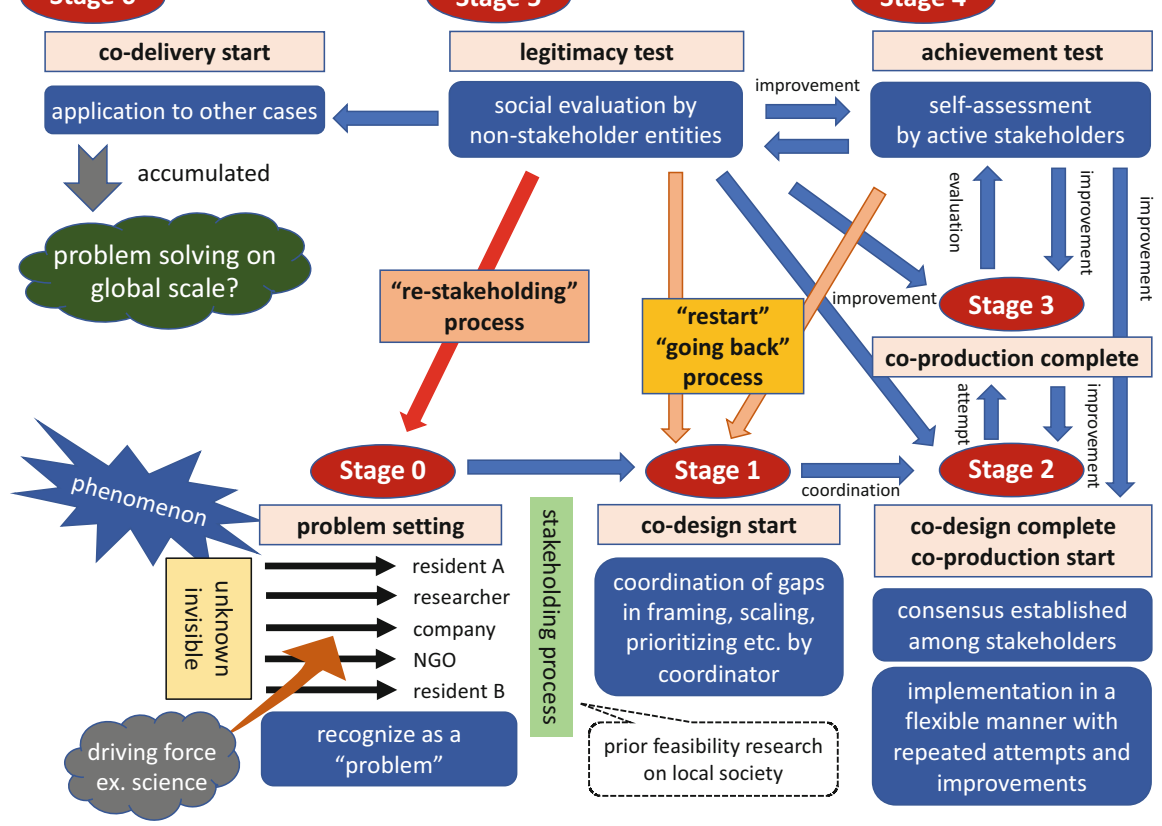
1

Fig. 2.1 Hypothetical timeline of the co-design, co-production, and co-delivery process

kind of conditions, requirements, and factors matter in which phase of the co-design/ co-production/co-delivery.

First of all, some phenomena and events occur in local communities or societies. It is often merely a phenomenon at this point, and is not necessarily recognized as a "problem" that should be resolved. It may be an invisible potential phenomenon in nature or the society that no one local, such as residents or administration, is aware of yet. In that case, some actors outside the local society may alert them to the phenomenon. In particular, scientists have a role of scientifically examining the meanings, mechanisms, and impacts of potential phenomena in nature and society that are invisible to general people and finally "visualizing" an invisible phenomenon. In this sense, the activities of outsiders, including scientists, can be a driving force (a trigger for problem-solving) that raises awareness of a problem to people of a local society.

In some cases, local people notice a phenomenon by themselves, and in other cases, they are made aware by knowledge from an outsider such as scientist. Whatever the case may be, some actors in a local society begin to understand the meaning and influence of a phenomenon and at last recognize it as a "problem." Subsequently, general residents, local government, corporations, and NPOs begin to make a "problem setting," but at this point they still stop at "potential" stakeholders (Stage 0). 
In order to solve the problem at the beginning of the collaborative project, "stakeholding" takes place to decide what kind of people and actors should be selected as "stakeholders." Each stakeholder usually has their own image of "framing," "scaling," and "prioritizing" the problem. They examine such images with each other and then the "co-design" phase begins (Stage 1). In the co-design process, stakeholders will check if the factors shown in the Gap Analysis Indicators (GAI) are consistently shared between themselves. When gaps between stakeholders are found, the coordination of these gaps is carried out under the leadership of a coordinator.

If the coordination of these gaps is concluded successfully and some kind of consensus or agreement is established, we can say that "co-design" has been achieved, and the next phase of "co-production" can start (Stage 2). However, it is essential that by the start of "co-production," all stakeholders should complete the work of reconciling their interests through communication and gaining a sense of mutual trust and satisfaction.

After that, stakeholders cooperate with each other to implement the project. This process proceeds in a flexible manner with repeated attempts and improvements. The reason is that social factors, such as interests, human relations, and financial problems among stakeholders, are usually unexpected and may impede or change the project plan. If a certain result is obtained while gradually improved, we can say that the "co-production" has been achieved (Stage 3).

However, this is not the end of the collaborative "co-design/co-production" process. "Co-production" rarely achieves complete problem resolution, and in many cases, it is necessary to repeat the "co-design/co-production" process. Therefore, at the stage where some kind of "co-production" outcome is obtained temporarily, internal evaluation or self-assessment will be carried out by the stakeholders who have jointly implemented the project thus far (Stage 4). Here, they evaluate whether the results of "co-production" are sufficient for the goal, if there was no problem in the "co-production" process. Then, such a temporal evaluation will be reflected in the next round of "co-production" in the form of a correction or improvement to the project. If they think that the result of "co-production" did not produce enough results, they may go back and again try the "co-design" process. In that case, it is not just a correction or improvement, but restarting the project from the "co-design" phase.

After a certain level of satisfactory results have been achieved while repeating internal evaluations, social evaluations by outsiders or non-stakeholder entities will be carried out (Stage 5). The internal evaluation in Stage 4 is self-evaluation by active stakeholders, and in some cases may fall into the category of "self-satisfaction." They may feel relieved that the project has been completed, and the assessment of whether the results actually contribute to problem-solving might be neglected. In addition, if the project was initiated with inappropriate "stakeholding," and those who should participate in the project were not able to, assessment from the perspective of excluded potential stakeholders will be very important. Likewise, it may be evaluated as imperfect because the problem should be dealt with on a larger or smaller scale. In that case, the appropriateness of "scaling" is reconsidered. In 
addition, internal stakeholders are likely to remain interested in problem-solving in their own society and are not interested in whether the results of their project can be applied in other cases. Therefore, it will also be important to see how this project will be evaluated from an outsider's perspective.

Thus, in order to examine the possibility of falling into "self-satisfaction," the relevance of "stakeholding," "scaling," and applicability to other cases, the viewpoint of outsiders or non-stakeholder entities is critically important. Social evaluation is open to other potential stakeholders, mass media, residents in other local societies, and people on national or global level who are interested in the problem.

The project will become "legitimate" only after it is fully evaluated from these external viewpoints. If it fails to obtain legitimacy, it may need to be improved, revised, or restarted. It might be required to go back to "co-production" (Stage 2) or "co-design" (Stage 1), or further return to the very first phase of "stakeholding" (Stage 0). More importantly, it is natural to repeat this process of going back and forth. Only after the "co-design/co-production" is repeated, re-examined, and improved, and if it passes the legitimacy test in social evaluation, will there be a possibility of applying it in other places. This phase is called "co-delivery" in the Future Earth framework (Stage 6).

Depending on the nature of the problem, generality of the solution process, and legitimacy of the final result, the conditions, and requirements for a successful "codesign/co-production" demonstrated in a certain society may spread to other regions. If such "co-delivery" cases are accumulated, they may have an impact on problemsolving on a global scale. In other words, although local stakeholders are not necessarily aiming to "scale up," the results of "co-design/co-production" projects and their implications may eventually diffuse to the global scale.

If this is the case, those who are responsible for contributing to global sustainability through the Future Earth framework are not local stakeholders involved in "co-design/co-production," but external subjects or non-stakeholder entities who join in the social evaluation of local projects and consider their applicability to other areas.

\section{Hypothetical Outline Map}

Figure 2.2 shows a hypothetical outline map that reconstructs the timeline of the "codesign/co-production/co-delivery" process from the perspective of the relationship between each phase. This figure will provide a clearer understanding of what conditions and factors are required in each phase of the collaborative process.

As a brief summary of this chapter, we will point out the six most important matters related to the hypothetical indicators of the conditions or requirements for a successful "co-design/co-production/co-delivery" process and future research issues.

First, it is very natural that various "gaps" arise between stakeholders in the process. Therefore, the starting point of "co-design/co-production/co-delivery" is to 


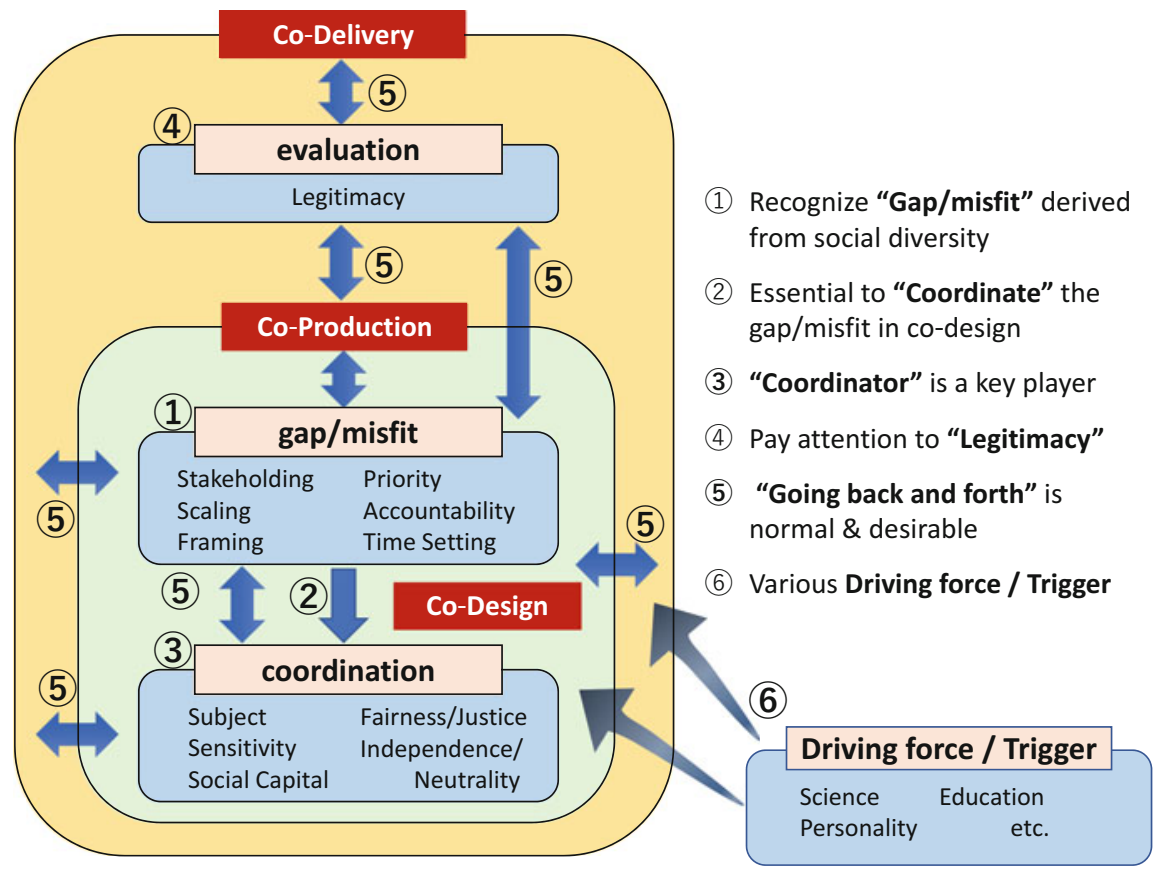

Fig. 2.2 Conditions and requirements for successful "co-design/co-production/co-delivery" in local society

recognize these "gaps" properly. This is a natural consequence of a diverse society, which is by no means monolithic; the problems proposed by scientists or researchers are not necessarily recognized in the same way by local stakeholders.

Second, it is important to fully understand the need to coordinate those "gaps" in all phases of the collaborative "co-design/co-production/co-delivery" process (especially in the phase of "co-design"). If you continue a collaborative project while leaving a "gap" as it is, it will result in the failure of "co-production," render social evaluation as illegitimate, and result in inapplicability to other areas or cases. This would be fatal to Future Earth, which aims to solve problems on a global scale.

Third, the role of a coordinator responsible for the mitigation of a "gap" is very important. The most important role of a coordinator is to build a relationship of mutual trust between stakeholders by keeping social sensitivity toward local interests. However, it is not yet clear what kind of characteristics, aptitudes, abilities, or attributes a coordinator should have, and this is a future issue. When scientists or researchers propose a collaborative "co-design/co-production/co-delivery" project, there are many cases where they will be responsible for coordination work by themselves. In that case, at the very least, we can say that scientists and researchers will be required to have human and social abilities to communicate with all stakeholders in addition to research capacity. 
Fourth, in order to ensure the achievement of the "co-design/co-production/codelivery" project and to secure the possibility of applying the results to other cases, social evaluation of legitimacy by non-stakeholder entities is important. Without the opportunity to test legitimacy, stakeholders may fall into "self-satisfaction" with internal evaluation that does not necessarily result in achieving their goals.

Fifth, the timeline of "co-design/co-production/co-delivery" is not a one-way process, and going back and forth is not only normal but also desirable. In "codesign/co-production/co-delivery" projects where the prospect of problem-solving is unpredictable and stakeholders with various interests are involved, it is quite rare for the original plan to proceed on schedule, and it is rather natural to repeat a continuous process of trial and error. By experiencing trial and error, it becomes possible to recognize and eliminate "gaps" between stakeholders and finally build a relationship of mutual trust. In other words, in the "co-design/co-production/codelivery" process, we should aim for flexible management that allows for the possibility of modifying or reworking the project, rather than strictly setting a plan or goal.

Sixth, there are some factors that will function as a driving force or trigger for promoting successful "co-design/co-production/co-delivery." They include the role of science in informing local stakeholders about the existence of problems, the combination of academic research and educational programs, and the personality attributes of key stakeholders that will affect these projects for better or worse. However, future research topics remain to consider whether there are other elements and what kind of effects they may have on the process.

\section{Conclusion}

In this chapter, we introduced our perspectives on Future Earth research and our own problem setting. Then, we proposed hypothetical indicators for the conditions, requirements, and processes for successful "co-design/co-production/co-delivery." Although such indicators still remain to be explored further, each chapter of this part will introduce and analyze each case based on this hypothesis. Table 2.1 is a list showing an outline of the analyses carried out based on the hypothetical indicators. Subsequent chapters will show the difficult struggles in executing "co-design/coproduction/co-delivery" in local societies. 
Table 2.1 Outline of the case studies in part 2 based on the hypothetical indicators

\begin{tabular}{|c|c|c|c|c|c|}
\hline \multicolumn{6}{|c|}{$\begin{array}{l}\text { (1) Gap Analysis Indicators (GAI): } \\
\text { Indicators to measure gaps between stakeholders }\end{array}$} \\
\hline & $\begin{array}{c}\text { Yokota } \\
\text { (India PHC) }\end{array}$ & $\begin{array}{c}\text { Sato } \\
\text { (Indonesia } \\
\text { Small hydropower) }\end{array}$ & $\begin{array}{l}\text { Fujiwara } \cdot \text { Onda } \\
\text { (Indonesia } \\
\text { Industrial tree } \\
\text { plantation) }\end{array}$ & $\begin{array}{c}\text { Hanamatsu } \cdot \\
\text { Tokunaga } \\
\text { (Kami-tsushima high } \\
\text { school) }\end{array}$ & $\begin{array}{c}\text { Hanamatsu } \\
\text { Yamashita } \\
\text { (Tsushima } \\
\text { Abandoned land) }\end{array}$ \\
\hline Stakeholding & $\begin{array}{l}\text { Multiple stakeholders with } \\
\text { different project time } \\
\text { phases since } 2015 \text {. } \\
\text { Stakeholders include Jaipur } \\
\text { District Department of } \\
\text { Medical, Health, and Family } \\
\text { Welfare, Kalwar Village, } \\
\text { Village Health Center, Saras } \\
\text { Dairy, Lotus Dairy Company, } \\
\text { Biyani Group of College, } \\
\text { Grameen Communications, } \\
\text { Kyushu University }\end{array}$ & $\begin{array}{l}\text { Residents, Leader of } \\
\text { traditional community, } \\
\text { Involved, local government, } \\
\text { researchers, NPOs and } \\
\text { private companies. As the } \\
\text { project progressed, the } \\
\text { network of stakeholders } \\
\text { gradually expanded. Active } \\
\text { stakeholders change by } \\
\text { phase. }\end{array}$ & $\begin{array}{l}\text { Kyushu University, Company, } \\
\text { NGOs, Residents, } \\
\text { Government (there are } \\
\text { conflicts within each } \\
\text { stakeholder) }\end{array}$ & $\begin{array}{l}\text { Stakeholders include Kami- } \\
\text { Tsushima High School, } \\
\text { Tsushima City, Tsushima } \\
\text { Commerce \& Industry } \\
\text { Association, Local } \\
\text { businessmen, Kyushu } \\
\text { University. The scope of } \\
\text { stakeholding was properly } \\
\text { limited. }\end{array}$ & $\begin{array}{l}\text { Stakeholders include Village } \\
\text { A, Tsushima City, Kyushu } \\
\text { University. However, the } \\
\text { Tsushima City's temporary } \\
\text { official staff as a good } \\
\text { coordinator withdrew from } \\
\text { the project halfway. On the } \\
\text { other hand, Village A } \\
\text { claimed a wider } \\
\text { stakeholding. }\end{array}$ \\
\hline Scaling & $\begin{array}{l}\text { Kalwar Village ( } 12,000 \\
\text { population) \& Saras Dairy } \\
\text { Manda Factory ( } 500 \\
\text { employees) }\end{array}$ & $\begin{array}{l}\text { Regional / district scale } \\
\text { (Ciptagelar village), but } \\
\text { similar problems can be } \\
\text { seen in various places. }\end{array}$ & $\begin{array}{l}\text { Industrial tree plantation } \\
\text { (approximately } 300,000 \text { ha), } \\
\text { scale depends on each } \\
\text { problem (e.g., biodiversity } \\
\text { conservation, land conflict, } \\
\text { economic development) }\end{array}$ & $\begin{array}{l}\text { Hitakatsu Area (900 } \\
\text { population in } 400 \\
\text { households) } \\
\text { The geographical, societal } \\
\text { scale were appropriate for } \\
\text { the purpose of the project. }\end{array}$ & $\begin{array}{l}\text { Village A ( } 180 \text { population in } \\
100 \text { households) } \\
\text { There was a gap on the } \\
\text { perception of scaling. } \\
\text { Whereas Kyushu University } \\
\text { group limited the scale into } \\
\text { the village, Village A claimed } \\
\text { a wider scale. }\end{array}$ \\
\hline Framing & $\begin{array}{l}\text { Framing is 「non- } \\
\text { communicable disease } \\
\text { prevention }\rfloor \text {. It was agreed } \\
\text { with all stakeholders. }\end{array}$ & $\begin{array}{l}\text { The problem of sustainable } \\
\text { energy self-sufficiency in } \\
\text { remote rural areas. }\end{array}$ & $\begin{array}{l}\text { Biodiversity conservation, } \\
\text { economic development, the } \\
\text { rights and livelihoods of } \\
\text { residents; the framing } \\
\text { differs by company, NGO, } \\
\text { residents, and scientists. }\end{array}$ & $\begin{array}{l}\text { Two framing was } \\
\text { successfully agreed with all } \\
\text { stakeholders; changing } \\
\text { consciousness of the local } \\
\text { people \& educating the local } \\
\text { high school students about } \\
\text { the local community. }\end{array}$ & $\begin{array}{l}\text { There was a great gap on } \\
\text { the perception of framing. } \\
\text { Kyushu University group } \\
\text { expected the reconversion } \\
\text { of abandoned farmland with } \\
\text { biodiversity and high profits } \\
\text { by making use of external } \\
\text { manpower. However, } \\
\text { Village A thought that the } \\
\text { problem of abandoning } \\
\text { farmland was entirely } \\
\text { caused by harmful wildlife } \\
\text { damage. }\end{array}$ \\
\hline Priority & $\begin{array}{l}\text { Not yet discussed about } \\
\text { [Priority] with local residents } \\
\text { but with other stakeholders, } \\
\text { it is agreed that our priority } \\
\text { to a prevention of non- } \\
\text { communicable diseases }\end{array}$ & $\begin{array}{l}\text { - Residents: Stable } \\
\text { electricity supply, Increase } \\
\text { in cash income } \\
\text { - Customary community } \\
\text { leader (Abah): Stable } \\
\text { electricity supply, } \\
\text { Conservation of traditional } \\
\text { culture } \\
\text { - Researchers: Looking for } \\
\text { ways to use renewable } \\
\text { energy sustainably in } \\
\text { remote areas } \\
\text { - Local government: } \\
\text { Improvement of } \\
\text { electrification rate }\end{array}$ & $\begin{array}{l}\text { - Companies: maximizing } \\
\text { profits and improving } \\
\text { reputation in the } \\
\text { international community } \\
\text { - NGO: emphasizing on } \\
\text { human rights and } \\
\text { environmental conservation } \\
\text { - Resident A: regaining land } \\
\text { rights } \\
\text { - Resident B: expecting an } \\
\text { increase in income } \\
\text { - Kyushu University: } \\
\text { mediating between NGOs } \\
\text { and company to promote } \\
\text { collaboration; conserving } \\
\text { biodiversity in protected } \\
\text { areas of the company }\end{array}$ & $\begin{array}{l}\text { All stakeholders agreed on } \\
\text { the priority of changing } \\
\text { consciousness of the local } \\
\text { people and educating the } \\
\text { local high school students } \\
\text { about the local community } \\
\text { by conducting continuous } \\
\text { elaborate meetings. Based } \\
\text { on such an agreement, each } \\
\text { stakeholder pursued their } \\
\text { own interest and role. }\end{array}$ & $\begin{array}{l}\text { There was a great gap on } \\
\text { the priority. Kyushu } \\
\text { University group expected } \\
\text { the reconversion of } \\
\text { abandoned farmland. } \\
\text { However, Village A gave } \\
\text { priority to the resolution of } \\
\text { harmful wildlife damage. }\end{array}$ \\
\hline $\begin{array}{l}\text { Accountability } \\
\text { (Responsibility) }\end{array}$ & $\begin{array}{l}\text { Shared cost and shared } \\
\text { responsibilities were agreed } \\
\text { among Kyushu University, } \\
\text { Biyani College, Grameen } \\
\text { Communications, and Lotus } \\
\text { Dairy Company in } 2019 .\end{array}$ & $\begin{array}{l}\text { - Local government is } \\
\text { responsible for } \\
\text { improvement of } \\
\text { electrification rate } \\
\text { - Local community is } \\
\text { responsible for electricity } \\
\text { supply to the residents } \\
\text { - Researchers support the } \\
\text { sustainable electricity self- } \\
\text { sufficiency }\end{array}$ & $\begin{array}{l}\text { - Companies: responsibility } \\
\text { for forest protection and } \\
\text { land conflicts in industrial } \\
\text { tree plantation areas } \\
\text { - Kyushu University: other } \\
\text { stakeholders expressed } \\
\text { concern about responsibility } \\
\text { for taking part in greenwash. }\end{array}$ & $\begin{array}{l}\text { All stakeholders agreed on } \\
\text { the sharing of responsibility. } \\
\text { High school wished to } \\
\text { continue project and take } \\
\text { responsibility byitself in } \\
\text { collaboration with Tsushima } \\
\text { City and Tsushima } \\
\text { Commerce \& Industry } \\
\text { Association, even after the } \\
\text { withdrawal of Kyyshu } \\
\text { University from the project. }\end{array}$ & $\begin{array}{l}\text { Joint project and shared } \\
\text { responsibilities were } \\
\text { pursued, but village A hoped } \\
\text { that Kyushu University } \\
\text { group should have assumed } \\
\text { the responsibility of the } \\
\text { project. }\end{array}$ \\
\hline Time Setting & $\begin{array}{l}\text { No urgency for time setting } \\
\text { but for long term time } \\
\text { setting is more required to } \\
\text { achieve our project } \\
\text { objectives (reduce new } \\
\text { cases of non-communicable } \\
\text { diseases (NCDs), increase } \\
\text { awareness, treatment, and } \\
\text { control of NCDs) }\end{array}$ & $\begin{array}{l}\text { Electricity supply is essential } \\
\text { for modern life. The power } \\
\text { outage problems should be } \\
\text { immediately resolved. }\end{array}$ & $\begin{array}{l}\text { - Company: making efforts } \\
\text { to improve reputation as a } \\
\text { priority issue. } \\
\text { - Kyushu University: hoping } \\
\text { to start conservation } \\
\text { activities as soon as possible } \\
\text { because there are rare plant } \\
\text { species in the protected } \\
\text { areas of the company }\end{array}$ & $\begin{array}{l}\text { The project was proposed in } \\
2015 \text {, first tried in } 2016 \text { and } \\
\text { developed in and after } 2017 . \\
\text { Trial and error was to some } \\
\text { degree achieved. No } \\
\text { urgency for time setting of } \\
\text { the project. However, as the } \\
\text { project is concerned with } \\
\text { education and change of } \\
\text { consciousness in local } \\
\text { people, more long time } \\
\text { setting is required to } \\
\text { achieve the project } \\
\text { objectives. }\end{array}$ & $\begin{array}{l}\text { Village A recognized no } \\
\text { urgency of the reconversion } \\
\text { of abandoned farmland. } \\
\text { However, it required an } \\
\text { urgent resolution of harmful } \\
\text { wildlife damage. Kyushu } \\
\text { University group did not } \\
\text { have much time left before } \\
\text { the end of the research } \\
\text { period and were urgent to } \\
\text { start the project. }\end{array}$ \\
\hline Transition Process & $\begin{array}{l}\text { No major conflicts or gaps } \\
\text { among stakeholders }\end{array}$ & $\begin{array}{l}\text { No major conflicts or gaps } \\
\text { among stakeholders }\end{array}$ & $\begin{array}{l}\text { There is a conflict, but no } \\
\text { time to resolve it. Kyushu } \\
\text { University and the company } \\
\text { collaborated in the } \\
\text { biodiversity assessment, but } \\
\text { it was not earned a } \\
\text { reputation from other } \\
\text { stakeholders. }\end{array}$ & $\begin{array}{l}\text { No major conflicts or gaps } \\
\text { among stakeholders } \\
\text { (By conducting continuous } \\
\text { elaborate meetings in co- } \\
\text { design phase, each } \\
\text { stakeholder's interests and } \\
\text { intentions are mutually } \\
\text { harmonized and } \\
\text { coordinated.) }\end{array}$ & $\begin{array}{l}\text { Great gaps on framing, } \\
\text { scaling, stakeholding, } \\
\text { priority, responsibility. } \\
\text { There was no enough time } \\
\text { for coordinating such gaps. }\end{array}$ \\
\hline
\end{tabular}


Table 2.1 (continued)

\begin{tabular}{|c|c|c|c|c|c|}
\hline \multicolumn{6}{|c|}{$\begin{array}{l}\text { (2) Social Consideration Indicators (SCI): } \\
\text { Indicators which coordinators should consider during the coordination process }\end{array}$} \\
\hline & $\begin{array}{c}\text { Yokota } \\
\text { (India PHC) }\end{array}$ & $\begin{array}{c}\text { Sato } \\
\text { (Indonesia } \\
\text { Small hydropower) }\end{array}$ & $\begin{array}{l}\text { Fujiwara } \cdot \text { Onda } \\
\text { (Indonesia } \\
\text { Industrial tree } \\
\text { plantation) }\end{array}$ & $\begin{array}{c}\text { Hanamatsu } \cdot \\
\text { Tokunaga } \\
\text { (Kami-tsushima high } \\
\text { school) }\end{array}$ & $\begin{array}{c}\text { Hanamatsu } \cdot \\
\text { Yamashita } \\
\text { (Tsushima } \\
\text { Abandoned land) }\end{array}$ \\
\hline Coordination Subject & Biyani Group of Colleges & $\begin{array}{l}\text { Kyushu University, AHB } \\
\text { (Association of Hydro } \\
\text { Bandung, just like NPO) }\end{array}$ & $\begin{array}{l}\text { Kyushu University (However, } \\
\text { it has not yet been } \\
\text { coordinated within teams of } \\
\text { Kyushu University. Kyushu } \\
\text { University has a team that } \\
\text { emphasizes collaboration } \\
\text { with the company and a } \\
\text { team that has a critical view } \\
\text { of the company, and each } \\
\text { team works with different } \\
\text { stakeholders.) }\end{array}$ & $\begin{array}{l}\text { The main coordinator is a } \\
\text { municipal temporary official } \\
\text { staff whereas this project } \\
\text { was jointly coordinated by } \\
\text { high school, Tsushima City } \\
\text { and Kyushu University. }\end{array}$ & $\begin{array}{l}\text { The coordinator is a } \\
\text { municipal temporary official } \\
\text { staff. However, Kyushu } \\
\text { University group by itself } \\
\text { tried to play the role of the } \\
\text { coordinator after the } \\
\text { municipal temporary official } \\
\text { withdrew from the project. }\end{array}$ \\
\hline Social Sensitivity & $\begin{array}{l}\text { Consultation and } \\
\text { communication with local, } \\
\text { district, state level } \\
\text { governments are already } \\
\text { done but with target } \\
\text { community residents are } \\
\text { not yet done }\end{array}$ & $\begin{array}{l}\text { Kyushu University, as a } \\
\text { project organizer, tried to } \\
\text { understand the local } \\
\text { cultures, history, } \\
\text { Socio-economic } \\
\text { circumstances, and visit the } \\
\text { site as much as possible } \\
\text { using student training } \\
\text { program. } \\
\text { However, there was a } \\
\text { limitation to visit } \\
\text { overseas sites. }\end{array}$ & $\begin{array}{l}\text { Insufficient although it is } \\
\text { necessary to fully hear the } \\
\text { opinions of each } \\
\text { stakeholder and carefully } \\
\text { present data while } \\
\text { maintaining independence } \\
\text { because there are severe } \\
\text { conflicts among } \\
\text { stakeholders }\end{array}$ & $\begin{array}{l}\text { Consultation and } \\
\text { communication with high } \\
\text { school, local businessmen } \\
\text { and residents were } \\
\text { sufficiently done. Much } \\
\text { attention has been paid to } \\
\text { human relationship in local } \\
\text { community. }\end{array}$ & $\begin{array}{l}\text { Lack of social sensitivity to a } \\
\text { local community as Kyushu } \\
\text { University group did not } \\
\text { carried out a detailed } \\
\text { hearing investigation to the } \\
\text { resident in the village. We } \\
\text { did not fully understand the } \\
\text { needs and priority of the } \\
\text { community. }\end{array}$ \\
\hline Social Capital & $\begin{array}{l}\text { To develop and strengthen } \\
\text { social capital, Kyushu Univ. } \\
\text { team had multiple face to } \\
\text { face meetings/discussions } \\
\text { with Biyani Group of College } \\
\text { (total of } 12 \text { times), with local, } \\
\text { district, and state } \\
\text { governments (2 times each), } \\
\text { and other stakeholders. }\end{array}$ & $\begin{array}{l}\text { By visiting the village as } \\
\text { much as possible (3-4 times } \\
\text { a year), talking and } \\
\text { investigating together, } \\
\text { human relations and } \\
\text { trusting relationships were } \\
\text { gradually nurtured. }\end{array}$ & $\begin{array}{l}\text { Trusting relationships have } \\
\text { not been developed among } \\
\text { conflicting stakeholders so } \\
\text { far. }\end{array}$ & $\begin{array}{l}\text { Robust trust relationships } \\
\text { between stakeholders was } \\
\text { successfully built owing to a } \\
\text { continuous elaborate } \\
\text { meetings and } \\
\text { communication between } \\
\text { high school students and } \\
\text { university group members. }\end{array}$ & $\begin{array}{l}\text { Kyushu University group } \\
\text { failed to build a trust } \\
\text { relationship with the leader, } \\
\text { main members and other } \\
\text { residents of the village A. } \\
\text { There was not enough time } \\
\text { left for bringing about a } \\
\text { relationship of trust with the } \\
\text { village. }\end{array}$ \\
\hline Fairness / Justice & $\begin{array}{l}\text { All stakeholders agreed that } \\
\text { "prevention of non- } \\
\text { communicable diseases" } \\
\text { and "improving an access to } \\
\text { health services" are } \\
\text { important and basic human } \\
\text { right. }\end{array}$ & $\begin{array}{l}\text { Because the power of the } \\
\text { leader (Abah) was great, we } \\
\text { took care to draw out the } \\
\text { real intentions of the local } \\
\text { residents as much as } \\
\text { possible. }\end{array}$ & $\begin{array}{l}\text { Kyushu University did not } \\
\text { give appropriate } \\
\text { consideration to conflicting } \\
\text { company, NGOs, and } \\
\text { residents while maintaining } \\
\text { independence (e.g., } \\
\text { publishing research results } \\
\text { in the media of the } \\
\text { company) }\end{array}$ & $\begin{array}{l}\text { High school, Tsushima City } \\
\text { and Kyushu University } \\
\text { conducted continuous } \\
\text { elaborate meetings on an } \\
\text { equal status, and } \\
\text { transmitted fully the result } \\
\text { of meeting to Tsushima } \\
\text { Commerce \& Industry } \\
\text { Association. Fair attention } \\
\text { had been paid to all } \\
\text { stakeholders. }\end{array}$ & $\begin{array}{l}\text { No fairness and justice in } \\
\text { that Kyushu University } \\
\text { group did not carried out a } \\
\text { detailed hearing } \\
\text { investigation to the resident } \\
\text { in the village and not fully } \\
\text { understand the needs and } \\
\text { priority of the community. }\end{array}$ \\
\hline $\begin{array}{l}\text { Independence / } \\
\text { Neutrality }\end{array}$ & $\begin{array}{l}\text { The project has certain } \\
\text { independence and } \\
\text { neutrality because we } \\
\text { signed on mutual } \\
\text { agreement to continue the } \\
\text { project until } 2020 \text {. But } \\
\text { could be fragile when } \\
\text { agreement is expired and } \\
\text { research budgets } \\
\text { completely exhausted. }\end{array}$ & $\begin{array}{l}\text { Since there was no conflict } \\
\text { composition, problems of } \\
\text { independence and } \\
\text { neutrality was not seen. }\end{array}$ & $\begin{array}{l}\text { No independence and } \\
\text { neutrality. It seems that the } \\
\text { provision of data on } \\
\text { biodiversity in response to a } \\
\text { request by the company is } \\
\text { neutral, but other } \\
\text { stakeholders recognize as } \\
\text { the behavior to justify the } \\
\text { company. }\end{array}$ & $\begin{array}{l}\text { Kyushu University group } \\
\text { played as an active } \\
\text { stakeholder, and did not } \\
\text { remain independent nor } \\
\text { neutral. However, it was no } \\
\text { problem because a } \\
\text { municipal temporary official } \\
\text { staff played as a main } \\
\text { neutral coordinator. }\end{array}$ & $\begin{array}{l}\text { Kyushu University group } \\
\text { played as an active } \\
\text { stakeholder, and did not } \\
\text { remain independent nor } \\
\text { neutral. At first, a municipal } \\
\text { temporary official staff } \\
\text { played as a main neutral } \\
\text { coordinator. However, he } \\
\text { withdrew from the project } \\
\text { halfway, and Kyushu } \\
\text { University group also tried } \\
\text { to become a neutral } \\
\text { coordinator but failed to do } \\
\text { it. }\end{array}$ \\
\hline
\end{tabular}

(continued) 
Table 2.1 (continued)

\begin{tabular}{|c|c|c|c|c|c|}
\hline \multicolumn{6}{|c|}{$\begin{array}{l}\text { (3) Social Evaluation Indicators (SEI): } \\
\text { Indicators to be considered during social evaluation }\end{array}$} \\
\hline & $\begin{array}{c}\text { Yokota } \\
\text { (India PHC) }\end{array}$ & $\begin{array}{c}\text { Sato } \\
\text { (Indonesia } \\
\text { Small hydropower) }\end{array}$ & $\begin{array}{c}\text { Fujiwara } \cdot \text { Onda } \\
\text { (Indonesia } \\
\text { Industrial tree } \\
\text { plantation) }\end{array}$ & $\begin{array}{c}\text { Hanamatsu } \\
\text { Tokunaga } \\
\text { (Kami-tsushima high } \\
\text { school) }\end{array}$ & $\begin{array}{l}\text { Hanamatsu } \\
\text { Yamashita } \\
\text { (Tsushima } \\
\text { Abandoned land) }\end{array}$ \\
\hline $\begin{array}{l}\text { Legitimacy } \\
\text { (All project phases) }\end{array}$ & $\begin{array}{l}\text { Legitimacy for this project } \\
\text { has not yet been discussed } \\
\text { with local community } \\
\text { residents but all } \\
\text { stakeholders recognized our } \\
\text { health project is legitimate } \\
\text { since it contribute to } \\
\text { increase people's access to } \\
\text { healthcare services as basic } \\
\text { human right. }\end{array}$ & Not yet evaluated. & $\begin{array}{l}\text { None (although there was } \\
\text { an agreement between } \\
\text { Kyushu University and } \\
\text { companies, social evaluation } \\
\text { by other stakeholders } \\
\text { including residents and } \\
\text { NGOs, was not obtained.) }\end{array}$ & $\begin{array}{l}\text { Legitimacy for this project } \\
\text { has not yet been fully } \\
\text { obtained through the } \\
\text { external social evaluation, } \\
\text { although it has already } \\
\text { passed internal evaluation } \\
\text { test among the active } \\
\text { relevant stakeholders. As } \\
\text { this project was taken up by } \\
\text { the local media and became } \\
\text { known to people in and } \\
\text { outside the island to a } \\
\text { certain extent, legitimacy } \\
\text { will be proved in the future. }\end{array}$ & $\begin{array}{l}\text { Legitimacy for this project } \\
\text { has absolutely not been } \\
\text { obtained through the } \\
\text { external social evaluation as } \\
\text { well as internal evaluation } \\
\text { among the relevant } \\
\text { stakeholders since Kyushu } \\
\text { University group withdrew } \\
\text { from the project without } \\
\text { coordinating several gaps in } \\
\text { the co-design phase. }\end{array}$ \\
\hline How to decide? & $\begin{array}{l}\text { We have consensus } \\
\text { meetings with stakeholders } \\
\text { for any important decisions } \\
\text { on our project. }\end{array}$ & $\begin{array}{l}\text { For local residents, Kyushu } \\
\text { University proposed a } \\
\text { method for solving } \\
\text { problems and received } \\
\text { approval from ethnic leader } \\
\text { Abah and the other } \\
\text { stakeholders. }\end{array}$ & $\begin{array}{l}\text { - Biodiversity assessment: } \\
\text { Kyushu University conducts } \\
\text { the assessment, and } \\
\text { companies use it as a } \\
\text { reference for decisions. } \\
\text { - Coordination between } \\
\text { expanding biodiversity } \\
\text { conservation area of the } \\
\text { company and appreciating } \\
\text { the rights of residents: no } \\
\text { progress }\end{array}$ & $\begin{array}{l}\text { Joint decision by all } \\
\text { stakeholders has been } \\
\text { developed through } \\
\text { continuous detailed meeting. }\end{array}$ & $\begin{array}{l}\text { Unilateral decision process: } \\
\text { Kyushu University group } \\
\text { proposed a project plan and } \\
\text { asked village A to accept it. }\end{array}$ \\
\hline $\begin{array}{l}\text { Who decide for } \\
\text { whom to whom? }\end{array}$ & $\begin{array}{l}\text { Biyani Colleges and Kyushu } \\
\text { university usually make } \\
\text { decisions on projects } \\
\text { activities based on local } \\
\text { target population's needs } \\
\text { after } \\
\text { consultations/discussions } \\
\text { with stakeholders }\end{array}$ & $\begin{array}{l}\text { For local residents, Kyushu } \\
\text { University proposed a } \\
\text { method for solving } \\
\text { problems and received } \\
\text { approval from ethnic leader } \\
\text { Abah and the other } \\
\text { stakeholders. }\end{array}$ & $\begin{array}{l}\text { For the company, the } \\
\text { research of Kyushu } \\
\text { University is positioned as a } \\
\text { tool to appeal the } \\
\text { conservation activities. }\end{array}$ & $\begin{array}{l}\text { Joint decision by all } \\
\text { stakeholders for local high } \\
\text { school students and local } \\
\text { people. }\end{array}$ & $\begin{array}{l}\text { Kyushu University group } \\
\text { tried to make a joint } \\
\text { decision with village A, but } \\
\text { village A suspected that } \\
\text { Kyushu University group } \\
\text { would decide and carry out } \\
\text { the project for their own } \\
\text { sake. }\end{array}$ \\
\hline $\begin{array}{l}\text { Usefulness of } \\
\text { Science }\end{array}$ & $\begin{array}{l}\text { Our project is based on } \\
\text { systematic research } \\
\text { methods and social \& } \\
\text { behavioral theories which } \\
\text { believed to be useful for the } \\
\text { implementation. }\end{array}$ & $\begin{array}{l}\text { Useful. The lack of scientific } \\
\text { and technical evaluation is a } \\
\text { part of the problem. }\end{array}$ & $\begin{array}{l}\text { Use of science for the basis } \\
\text { of corporate profits and CSR. }\end{array}$ & $\begin{array}{l}\text { Scientific technics or tools } \\
\text { have not been used except } \\
\text { for a questionnaire survey. } \\
\text { However, there was some } \\
\text { possibility that the reliance } \\
\text { on the scientific and } \\
\text { educational knowledge of } \\
\text { Kyushu University enabled } \\
\text { other stakeholders to try } \\
\text { this project. }\end{array}$ & $\begin{array}{l}\text { Neither trust nor doubt } \\
\text { were heard among residents } \\
\text { of the village about scientific } \\
\text { knowledge on biodiversity } \\
\text { and technology for } \\
\text { improving productivity. The } \\
\text { fact that the project was to } \\
\text { be based on scientific } \\
\text { knowledge and technology } \\
\text { did not seem to have a } \\
\text { direct influence on the } \\
\text { judgment of the residents. }\end{array}$ \\
\hline Social Sensitivity & $\begin{array}{l}\text { Sensitivity to local } \\
\text { community residents is not } \\
\text { sufficient since no } \\
\text { consultations or discussions } \\
\text { are made, but sensitivity to } \\
\text { other stakeholders are } \\
\text { considered to be sufficient } \\
\text { since number of face-to-face } \\
\text { meetings and site visits } \\
\text { were made. }\end{array}$ & $\begin{array}{l}\text { Ciptagelar is a village where } \\
\text { traditional culture remains, } \\
\text { so that the consideration } \\
\text { was made not to } \\
\text { inadvertently damage the } \\
\text { natural environment or } \\
\text { culture. }\end{array}$ & $\begin{array}{l}\text { Careful consideration to } \\
\text { conduct research was not } \\
\text { adequate in intense conflicts } \\
\text { among stakeholders. }\end{array}$ & $\begin{array}{l}\text { Consultation and } \\
\text { communication with high } \\
\text { school, local businessmen } \\
\text { and residents were } \\
\text { sufficiently done. Much } \\
\text { attention has been paid to } \\
\text { human relationship in local } \\
\text { community. }\end{array}$ & $\begin{array}{l}\text { Lack of social sensitivity to a } \\
\text { local community as Kyushu } \\
\text { University group did not } \\
\text { carried out a detailed } \\
\text { hearing investigation to the } \\
\text { resident in the village. We } \\
\text { did not fully understand the } \\
\text { needs and priority of the } \\
\text { community. }\end{array}$ \\
\hline
\end{tabular}

(continued) 
Table 2.1 (continued)

\begin{tabular}{|c|c|c|c|c|c|}
\hline \multicolumn{6}{|c|}{ (4) Additional Factors (AF) } \\
\hline & $\begin{array}{c}\text { Yokota } \\
\text { (India PHC) }\end{array}$ & $\begin{array}{c}\text { Sato } \\
\text { (Indonesia } \\
\text { Small hydropower) }\end{array}$ & $\begin{array}{c}\text { Fujiwara } \cdot \text { Onda } \\
\text { (Indonesia } \\
\text { Industrial tree } \\
\text { plantation) }\end{array}$ & $\begin{array}{c}\text { Hanamatsu } \\
\text { Tokunaga } \\
\text { (Kami-tsushima high } \\
\text { school) }\end{array}$ & $\begin{array}{c}\text { Hanamatsu • } \\
\text { Yamashita } \\
\text { (Tsushima } \\
\text { Abandoned land) }\end{array}$ \\
\hline Personality & $\begin{array}{l}\text { Most stakeholder leaders } \\
\text { are supportive, positive, } \\
\text { open-minded, and willing to } \\
\text { make social impacts. }\end{array}$ & $\begin{array}{l}\text { The ethnic leader Abah has } \\
\text { two opposite aspects: A } \\
\text { young man who love the } \\
\text { latest electronic technology } \\
\text { and crafts./ A shaman who is } \\
\text { a spiritual pillar of local } \\
\text { traditional culture. }\end{array}$ & $\begin{array}{l}\text { The influence of business } \\
\text { judgment by the company is } \\
\text { considerable. } \\
\text { The pressure from NGOs } \\
\text { affects business judgment in } \\
\text { many cases. }\end{array}$ & $\begin{array}{l}\text { This project was highly } \\
\text { dependent on the } \\
\text { personality of the } \\
\text { temporary municipal } \\
\text { officials, but the adverse } \\
\text { effects of the change of } \\
\text { particular stakeholders were } \\
\text { overcome by the } \\
\text { relationship of trust and } \\
\text { communication among } \\
\text { other stakeholders. }\end{array}$ & $\begin{array}{l}\text { Personality of the village } \\
\text { leader had a great impact. } \\
\text { Change of leader caused a } \\
\text { reversal of the project. On } \\
\text { the other hand, this project } \\
\text { was highly dependent on } \\
\text { the personality of the } \\
\text { temporary municipal official. } \\
\text { His withdrawal had a great } \\
\text { adverse influence on the } \\
\text { project. }\end{array}$ \\
\hline $\begin{array}{l}\text { Integration of } \\
\text { scientific research \& } \\
\text { education }\end{array}$ & $\begin{array}{l}\text { Currently only research not } \\
\text { educational activities yet. }\end{array}$ & $\begin{array}{l}\text { Integration of scientific } \\
\text { research \& education was } \\
\text { useful. } \\
\text { Student educational } \\
\text { activities consisting of } \\
\text { various specialized students } \\
\text { helped to understand the } \\
\text { community. }\end{array}$ & Research-only stage & $\begin{array}{l}\text { This research project was } \\
\text { closely connected with } \\
\text { educational programs such } \\
\text { as "citizenship education" of } \\
\text { local high school students } \\
\text { and fieldwork activities by } \\
\text { graduate students of Kyushu } \\
\text { University. }\end{array}$ & $\begin{array}{l}\text { Only research } \\
\text { (This project was expected } \\
\text { to connect with educational } \\
\text { programs in high school and } \\
\text { university in the future, but } \\
\text { finally given up before } \\
\text { discussing a detailed plan.) }\end{array}$ \\
\hline others & $\begin{array}{l}\text { Frequent and continuous } \\
\text { dialogues, meetings, and } \\
\text { discussions are necessary to } \\
\text { maintain the project to be } \\
\text { sustainable. Long term } \\
\text { official written agreements } \\
\text { are also necessary to keep } \\
\text { stakeholders to be } \\
\text { accountable. }\end{array}$ & $\begin{array}{l}\text { Characteristic of local } \\
\text { culture was important. The } \\
\text { village has a idea of pair } \\
\text { (Male \& Female, Sky \& earth } \\
\text { etc.) } \\
\text { Due to the idea, modern } \\
\text { technology is easily } \\
\text { accepted, without } \\
\text { contradicting with the } \\
\text { conservation of the } \\
\text { traditional cultures. }\end{array}$ & $\begin{array}{l}\text { There was a consultation } \\
\text { from the company. It has } \\
\text { difficulty making } \\
\text { collaboration in social } \\
\text { aspects due to the lack of } \\
\text { information provided by the } \\
\text { company. }\end{array}$ & $\begin{array}{l}\text { Coordination by municipal } \\
\text { temporary official staffs } \\
\text { were excellent. Success of } \\
\text { this project was due mainly } \\
\text { to the work of such } \\
\text { coordinators. }\end{array}$ & $\begin{array}{l}\text { Withdrawal of the municipal } \\
\text { temporary official staff from } \\
\text { the project had a great } \\
\text { adverse influence on the } \\
\text { project. Failure of this } \\
\text { project was mainly caused } \\
\text { by the subsequent absence } \\
\text { of a neutral coordinator. }\end{array}$ \\
\hline
\end{tabular}

Acknowledgments This work was supported by a grant JPMJRX16F1 from the Research Institute of Science and Technology for the Society (RISTEX) of Japan Science and Technology Agency (JST) as part of the Future Earth programs, and JSPS Grants-in-Aid for Scientific Research Grant Number 17H02491 and 17K18531.

\section{References}

Asayama S, Emor S, Masuda K (2017) Toward reflective advocacy in climate controversy: complex boundaries between science and policy. Sociotechnica 14:21-37

Bache I, Flinders M (2004) Multi-level governance. Oxford University Press, Oxford

Brown VA, Harris JA, eds RJY (2010) Tackling wicked problems: through the transdisciplinary imagination. Routledge, London

Coicaud JM (2002) Legitimacy and politics: a contribution to the study of political right and political responsibility. Cambridge University Press, Cambridge

Edwards M (2014) Civil society, 3rd edn. Polity Press, Cambridge

Ehrenberg JR (2017) Civil society: the critical history of an idea, 2nd edn. New York University Press, New York

Freeman RE, Harrison JS, Wicks AC, Parmar BL, de Colle S (2010) Stakeholder theory: the state of the art. Cambridge University Press, Cambridge

Funtowicz SO, Ravetz JR (1993) Science for the post-normal age. Futures 25:739-755

Future Earth (2013) Future earth initial science report. International Council for Science, Paris

Future Earth (2014) Strategic research agenda 2014: priorities for a global sustainability research strategy. International Council for Science, Paris

Hanamatsu Y (2012) National boundaries and the fragmentation of governance systems: AmurOkhotsk ecosystem from the legal and political perspective. In: Taniguchi M, Shiraiwa T (eds) The dilemma of boundaries: toward a new concept of catchment. Springer, New York, pp $123-143$ 
Herod A (2011) Scale. Routledge, London

Jasanoff S (2010) A new climate for society. Theory Culture Soc 27:233-253

Jonas AEG (2015) Scale. In: Agnew J, Mamadouh V, Secor A, Sharp J (eds) The Wiley Blackwell companion to political geography. Wiley-Blackwell, Chichester, pp 26-34

Kurtz HE (2003) Scale frames and counter-scale frames: constructing the problem of environmental injustice. Polit Geogr 22:887-916

Latham A (2002) Retheorizing scale of globalization: topologies, actor-networks and cosmopolitanism. In: Herod A, Wright MW (eds) Geographies of power: placing scale. Blackwell Publishing, Hoboken, pp 115-144

Lövbrand E, Beck S, Chilvers J, Forsyth T, Hedrén J, Hulme M, Lidskog R, Vasileiadou E (2015) Who speaks for the future of earth?: How critical social science can extend the conversation on the anthropocene. Glob Environ Chang 32:211-218

Mitchell RK, Agle BR, Wood DJ (1997) Toward a theory of stakeholder identification and salience: defining the principle of who and what really counts. Acad Manag Rev 22:853-886

Moser SC (2016) Can science on transformation transform science? Lessons from co-design. Curr Opin Environ Sustain 20:106-115

O’Brien K, Barnett J (2013) Global environmental change and human security. Annu Rev Environ Resour 38:373-391

Pielke RA (2007) The honest broker: making sense of science in policy and politics. Cambridge University Press, Cambridge

Putnam RD (1993) Making democracy work: civic traditions in modern Italy. Princeton University Press, Princeton

Putnam RD (2000) Bowling alone: the collapse and revival of American community. Simon \& Schuster, New York

Smith N (1992) Geography, difference, and the politics of scale. In: Doherty J, Graham E, Malek M (eds) Postmodernism and the social sciences. MacMillan, Basingstoke, pp 55-79

Stafford-Smith M, Gaffney O, Brito L, Ostrom E, Seitzinger S (2012) Interconnected risks and solutions for a planet under pressure-overview and introduction. Curr Opin Environ Sustain $4: 3-6$

Swyngedouw E (1997) Excluding the other: the production of scale and scaled politics. In: Lee R, Wills J (eds) Geographies of economies. Routledge, London, pp 167-176

Swyngedouw E (2004) Scaled geographies: nature, place, and the politics of scale. In: Sheppard E, McMaster RB (eds) Scale and geographic inquiry: nature, society and method. Blackwell Publishers, Hoboken, pp 129-153

Swyngedouw E (2011) The non-political politics of climate change. ACME 12:1-8

Swyngedouw E (2014) Anthropocenic politicization: from the politics of the environment to politicizing environments. In: Bradley K, Hedrén J (eds) Green Utopianism: perspectives, politics and micro-practices. Routledge, London, pp 23-37

Turnhout E, Boonman-person S (2012) Databases, scaling practices, and the globalization of biodiversity. Ecol Soc 16:35-48

Van der Hel S (2016) New science for global sustainability? The institutionalization of knowledge co-production in future earth. Environ Sci Pol 61:165-175

Weinberg AM (1972) Science and trans-science. Minerva 10:209-222

Werlen B (2015) Global sustainability, cultural perspectives and challenges for transdisciplinary integrated research. Springer, New York

Yohannan F, Obinna P, Polman N, Termeer C (2014) Scale-sensitive governance of the environment. Wiley-Blackwell, Hoboken

Yokota F, Biyanic M, Islam R, Ashir A, Nishikitani M, KikuchKi NY, Nakashima N (2018) Lessons learned from co-design and co-production in a portable health clinic research project in Jaipur District, India (2016-2018). Sustainability 10:4148

Zalasiewicz J, Williams M, Steffen W, Crutzen P (2010) The new world of the anthropocene. Environ Sci Technol 44:2228-2231 
Open Access This chapter is licensed under the terms of the Creative Commons Attribution 4.0 International License (http://creativecommons.org/licenses/by/4.0/), which permits use, sharing, adaptation, distribution and reproduction in any medium or format, as long as you give appropriate credit to the original author(s) and the source, provide a link to the Creative Commons license and indicate if changes were made.

The images or other third party material in this chapter are included in the chapter's Creative Commons license, unless indicated otherwise in a credit line to the material. If material is not included in the chapter's Creative Commons license and your intended use is not permitted by statutory regulation or exceeds the permitted use, you will need to obtain permission directly from the copyright holder. 